\title{
COMPARISON BETWEEN MODERN POLAR AND TEMPERATE SKELETAL CARBONATE MINERALOGY AND OXYGEN AND CARBON ISOTOPES, ANTARCTIC AND TASMANIAN SHELVES
}

\author{
by C. Prasada Rao, Zahra Z. Amini and Dennis C. Franklin \\ (with one table and eight text-figures)
}

C.P. RaO, Amini, Z.Z. \& Franklin, D.C., 1996 (xi): Comparison between modern polar and temperate skeletal carbonate mineralogy and oxygen and carbon isotopes, Antarctic and Tasmanian shelves. In Banks, M.R. \& Brown, M.J. (Eds): CLIMATIC SUCCESSION AND GLACIAL HISTORY OF THE SOUTHERN HEMISPHERE OVER THE LAST FIVE MILLION YEARS. Pap. Proc. R. Soc. Tasm. 130 (2): 87-93. https://doi.org/10.26749/rstpp.130.2.87 ISSN 0080-4703. Department of Geology (CPR, ZZA) and Antarctic CRC (DCF), University of Tasmania, GPO Box 252-80, Hobart, Tasmania, Australia 7001.

\begin{abstract}
Modern bryozoan skeletal mineralogy varies with seawater temperature: polar Antarctic bryozoans are mainly low-Mg calcite, whereas temperate Tasmanian bryozoans are predominantly high- $\mathrm{Mg}$ calcite with variable amounts of aragonite. Bivalve molluscs from both polar and temperate regions are mainly aragonite with variable amounts of low-Mg calcite. The $\delta^{18} \mathrm{O}$ and $\delta^{13} \mathrm{C}$ isotope fields of polar skeletons are clearly separated from the temperate fields, due to differences in seawater temperatures, levels of $\delta^{13} \mathrm{C}$ in seawater and the circulation of seawater masses. $\delta^{18} \mathrm{O}$ values of bryozoa, benthic foraminifera and bivalve molluscs give near-equilibrium seawater temperatures. Small differences in $\delta^{18} \mathrm{O}$ and $\delta^{13} \mathrm{C}$ values between skeletons are due to their variable growth rates. Meltwater effects are small $(<7 \%)$ in the polar Antarctic Sea and high $(<25 \%)$ in the shallow Arctic Sea because ice sheets do not melt in the Antarctic region, whereas significant melting of ice sheets occurs in summer in the Arctic regions. Skeletal carbonate mineralogy and $\delta^{18} \mathrm{O}$ and $\delta^{13} \mathrm{C}$ variations can be used in the recognition of ancient, non-tropical carbonate skeletons and carbonate rocks.
\end{abstract}

Key Words: Recent cold-water carbonates, carbonate mineralogy, oxygen and carbon isotopes, Antarctica, Tasmania.

\section{INTRODUCTION}

Carbonate skeletons are abundant in modern shallow seas from tropical, temperate to polar regions. Accumulation of carbonate skeletons forms carbonates in all climatic regions. Temperate and polar carbonates are mainly biogenic sediments (e.g. Domack 1988, Nelson 1988, Taviani \& Aharon 1989, Anderson et al. 1992). The carbonate mineralogy of many skeletons varies with seawater temperatures (e.g. Morse \& McKenzie 1990, Rao 1993). Comparison of carbonate skeletal mineralogy from temperate and polar sediments is presented here to illustrate temperature control on carbonate skeletal mineralogy.

The ${ }^{18} \mathrm{O}$ fractionation related to water temperature is well established (e.g. Friedman \& O'Neil 1977). The ${ }^{13} \mathrm{C}$ in surface seawater varies from temperate to polar regions, due to atmospheric $\mathrm{CO}_{2}$, oxidation of organic matter and mixing of water masses (Kroopnick 1985). Rate of skeletal precipitation affects the $\delta^{18} \mathrm{O}$ and $\delta^{13} \mathrm{C}$ composition of skeletons (c.g. McConnaughey 1989). This study presents $\delta^{18} \mathrm{O}$ and $\delta^{13} \mathrm{C}$ fields for polar Antarctic bryozoans, benthic foraminifera and bivalve molluscs, compares these fields with those of similar fauna previously established for the subpolar Greenland Shelf and for the temperate Tasmanian Shelf (fig. 1; Rao 1994) and discusses relative rates of skeletal precipitation of polar Antarctic bryozoans, benthic foraminifera and bivalve molluscs. The implications of our findings in understanding the origin of modern and ancient temperate to polar skeletal accumulations are presented.

\section{METHODS OF STUDY}

Tasmanian samples studied are grab samples from eastern Tasmania (fig. 1; Rao 1993) and range from about 30 to $200 \mathrm{~m}$ water depths. Antarctic samples from the Prydz Bay
Shelf (fig. 1) are grab samples at water depths from 0 to $121 \mathrm{~m}$ and from a $0.6 \mathrm{~m}$ long, deep core (with samples at about $25 \mathrm{~mm}$ intervals) at $134 \mathrm{~m}$ water depth. Both Tasmanian and Antarctic samples range from siliciclastics to carbonates. However, Tasmanian samples are mainly carbonates, whereas Antarctic ones are predominantly siliciclastics. After washing the samples, bryozoans, benthic foraminifera and bivalves were hand-picked using a binocular microscope. Bryozoans and bivalves were subjected to X-ray

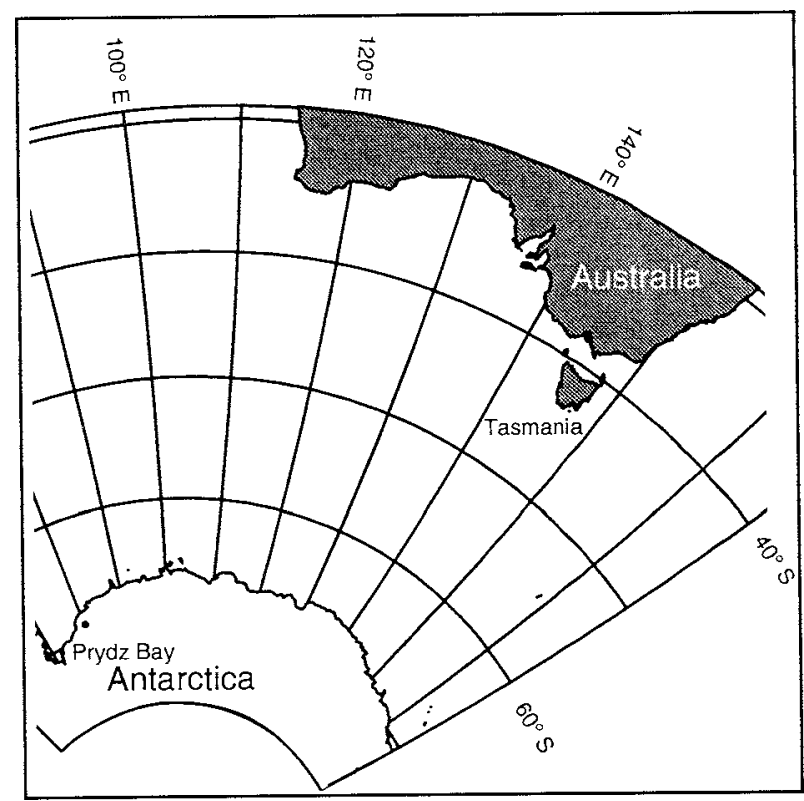

FIG. 1 - Location of Tasmania, Australia, and Prydz Bay, Antarctica. Note - Tasmania is in the cool temperate region and Prydz Bay is in the polar region. 
diffractometry for carbonate minerals. Skeletons from Tasmania and Antarctica were reacted with 100\% anhydrous $\mathrm{H}_{3} \mathrm{PO}_{4}$ at $25^{\circ} \mathrm{C}$. The evolved $\mathrm{CO}_{2}$ gas was analysed on a VG SIRA series II mass-spectrometer at the University of Tasmania for $\delta^{18} \mathrm{O}$ and $\delta^{13} \mathrm{C}$, the values being expressed in conventional per mil notation relative to the PDB standard. The precision of data, established from duplicate analysis, is t0.1\% for both $\mathrm{O}$ and C. Data used in this study are from shallow seawater depths $(<399 \mathrm{~m})$ : bryozoan and bivalve molluscan mineralogy and $\delta^{18} \mathrm{O}$ and $\delta^{13} \mathrm{C}$ values of bryozoans, benthic foraminifera and bivalve molluscs from Antarctica and bivalve molluses from Tasmania (table 1); ${ }^{14} \mathrm{C}$ dates obtained from hand-picked fauna and sediments from Prydz Bay (Harris et al. 1996); $\delta^{18} \mathrm{O}$ and $\delta^{13} \mathrm{C}$ values of aragonite bivalves from Greenland (Israelson et al. 1994).

\section{RADIOCARBON AGES OF ANTARCTIC SEDIMENTS}

The ${ }^{14} \mathrm{C}$ dates of 17 grab samples from Prydz Bay range from 2470 to $140 \mathrm{yr}$ BP. Two dates are from cores (GCO3) are $4314 \pm 96 \mathrm{yr} \mathrm{BP}$ at $0.15 \mathrm{~cm}$ and $8030 \pm 100 \mathrm{yr} \mathrm{BP}$ at 0.55 to $0.57 \mathrm{~m}$. In Antarctica, many living marine organisms yield older ${ }^{14} \mathrm{C}$ ages - up to 1770 yr BP (Stuiver et al. 1981) - because the ${ }^{14} \mathrm{C}$ reservoir effect is pronounced around Antarctica (Harris et al. 1996). All these ages firmly establish that the Antarctic sediments studied here were deposited during the Late Holocene.

\section{CARBONATE MINERALOGY}

X-ray diffractometric analyses indicate that Antarctic bryozoans are calcites with a predominance of low-Mg calcite $\left(<5 \%\right.$ mole $\% \mathrm{MgCO}_{3}$ ) relative to high- $\mathrm{Mg}$ calcite ( $>5$ mole $\% \mathrm{MgCO}_{3}$; fig. 2 ), whereas temperate Tasmanian bryozoans (Rao 1993) are mainly high-Mg calcite with variable amounts of aragonite up to $90 \%$ (fig. 2). Bivalve molluscs from Antarctica and Tasmania are mainly aragonite with variable amounts of calcite up to $90 \%$ (fig. 3 ). The type of calcite in bivalve molluses is low-Mg calcite. X-ray $\mathrm{d}$ spacings of Antarctic bryozoan calcite reveal that mole $\% \mathrm{Mg}$ in this calcite ranges from about 1 to $8 \%$ with most being less than 5\% (fig. 2). Experimental studies on abiotic calcite demonstrate that mole $\% \mathrm{MgCO}_{3}$ decreases with decreasing seawater temperatures (fig. 4; Kinsman \& Holland 1969, Fuchtbauer \& Hardie 1976, Mucci 1987, Burton \& Walter 1991). Comparison of bryozoan mole $\% \mathrm{MgCO}_{3}$, obtained from $\mathrm{X}$-ray $\mathrm{d}$-spacings, and temperatures, calculated from $\delta^{18} \mathrm{O}$ values of bryozoans, shows that the calcite mineralogy and mole $\% \mathrm{MgCO}_{3}$ of bryozoans vary with seawater temperatures, as do those of abiotic calcites. The low- $\mathrm{Mg}$ calcite bryozoans mainly grow in cold $\left(-2^{\circ} \mathrm{C}\right)$ Antarctic seawater and predominantly high-Mg calcite bryozoans grow in cool $\left(7^{\circ}-13^{\circ} \mathrm{C}\right)$ temperate Tasmanian shelf water (fig. 4).

\section{OXYGEN AND CARBON ISOTOPES}

The $\delta^{18} \mathrm{O}$ values of polar Antarctic bryozoans (2.89-4.17), benthic foraminifera $(2.89-4.20)$ and bivalve molluscs (3.415.01) are more positive than those of similar fauna from the temperate Tasmanian Shelf (fig. 5). In contrast to $\delta^{18} \mathrm{O}$ values, $\delta^{13} \mathrm{C}$ values of polar Antarctic bryozoans $(-0.15$ to $1.93)$, benthic foraminifera $(-0.71$ to 1.30$)$ and bivalve molluscs $(-1.07$ to 1.72$)$ overlap and extend to lower values compared with similar skeletons from the temperate Tasmanian Shelf (fig. 5). Both Tasmanian and Antarcric isotope fields are below the temperature equilibrium lines of calcite and aragonite equilibrium with surface seawater (Rao 1993), because these non-tropical carbonates are in equilibrium with bottom seawater. High positive $\delta^{18} \mathrm{O}$ values and lack of negative $\delta^{18} \mathrm{O}$ values on Antarctic skeletons indicate that melt-water dilution is minimal in the samples studied, as expected (Taviani \& Aharon 1989, Taviani et al. 1993).

The $\delta^{18} \mathrm{O}$ values of Antarctic and Tasmanian fauna are related to seawater temperatures, which can be calculated with ${ }^{18} \mathrm{O}$ thermometry. These calculated temperature ranges (fig. 5) are similar for bryozoa $\left(-3^{\circ}\right.$ to $\left.3^{\circ} \mathrm{C}\right)$, benthic foraminifera $\left(-3^{\circ}\right.$ to $\left.3^{\circ} \mathrm{C}\right)$ and bivalve molluscs $\left(-3^{\circ}\right.$ to $\left.5^{\circ} \mathrm{C}\right)$. Since the average Antarctic seawater temperature is approximately $-2^{\circ} \mathrm{C}$ (actually $-1.98^{\circ}$ to $-1.87^{\circ} \mathrm{C}$ ), equilibrium $\delta^{18} \mathrm{O}$ lines are drawn for calcite and aragonite at $-2^{\circ} \mathrm{C}$, using $\delta^{18} \mathrm{O}$ equations of calcite and aragonite mollusca (Grossman \& Ku 1986). Eighty percent of bryozoan $\delta^{18} \mathrm{O}$ values fall on the low-Mg calcite equilibrium line at $-2^{\circ} \mathrm{C}$ (fig. $5 \mathrm{~A}$ ), confirming that bryozoan $\delta^{18} \mathrm{O}$ values are reliable indicators of seawater temperatures. Bryozoans that indicate warmer temperatures than $-2^{\circ}$ are high-Mg calcite. Benthic foraminifera $\delta^{18} \mathrm{O}$ values fall on the low-Mg calcite equilibrium line at $-2^{\circ} \mathrm{C}$ and deviate to lower $\delta^{18} \mathrm{O}$ values (fig. $5 \mathrm{~B}$ ), thus indicating relatively warmer seawater temperatures. Bivalve mollusca $\delta^{18} \mathrm{O}$ values fall at the edge of the aragonite equilibrium line at $-2^{\circ} \mathrm{C}$ and deviate to lower values (fig. $5 \mathrm{C}$ ), thus indicating relatively warmer seawater temperacures. The low-Mg calcite equilibrium line at $-2^{\circ} \mathrm{C}$ dissects the bivalve mollusca isorope field, due to the occurrence of variable amounts of low- $\mathrm{Mg}$ calcite in bivalve molluses (fig. 5C). Antarctic bivalve molluses (Adamussium colbecki and Laternula elliptica)were demonstrated to show different $\delta^{18} \mathrm{O}$ values in various parts of the skeletons (Barrera et al. 1994), which should be the case for crushed bulk bivalves analysed in this study. Despite this apparent variation in $\delta^{18} \mathrm{O}$ values in different parts of the shell, the Antarctic bulk bivalve molluscs provide near equilibrium isotopic estimates of seawater temperatures (Barrera et al. 1994).

$\delta^{18} \mathrm{O}$ values of Antarctic bivalves are much higher than those of bivalves from shallow ( $<30 \mathrm{~m}$ ) depths in the Arctic Sea around Greenland (fig. 6). Though measured seawater temperatures around Greenland are very cold and range from $-1.8^{\circ}$ to $1^{\circ} \mathrm{C}$, the temperatures calculated from $\delta^{18} \mathrm{O}$ values of bivalves give anomalously warm temperatures ranging from $9^{\circ}$ to $21^{\circ} \mathrm{C}$. These high temperatures are due to strong meltwater dilution of up to $25 \%$ (fig. 6) that reduces the $\delta^{18} \mathrm{O}$ of seawater from 0 to $-9 \%$ SMOW (fig. 7), because measured melrwater $\delta^{18} \mathrm{O}$ values around Greenland are around $-38 \%$ SMOW. The temperatures warmer than $-1.8^{\circ} \mathrm{C}$, obtained from some bryozoans, benthic foraminifera and bivalves from Antarctica, are possibly due to small amounts $(<7 \%)$ of meltwater. This amount of meltwater around Antarctica is calculated from the most negative $\delta^{18} \mathrm{O}$ value of $2.9 \%$ and a carbonatewater fractionation factor $\left(\Delta^{18} \mathrm{O}\right)$ of $35 \%$ at $-2^{\circ} \mathrm{C}$ (Rao $\&$ Green 1982).

$\delta^{18} \mathrm{O}$ values lower than equilibtium lines of low- $\mathrm{Mg}$ calcite and aragonite at $-2^{\circ} \mathrm{C}$ in all fauna are probably due 


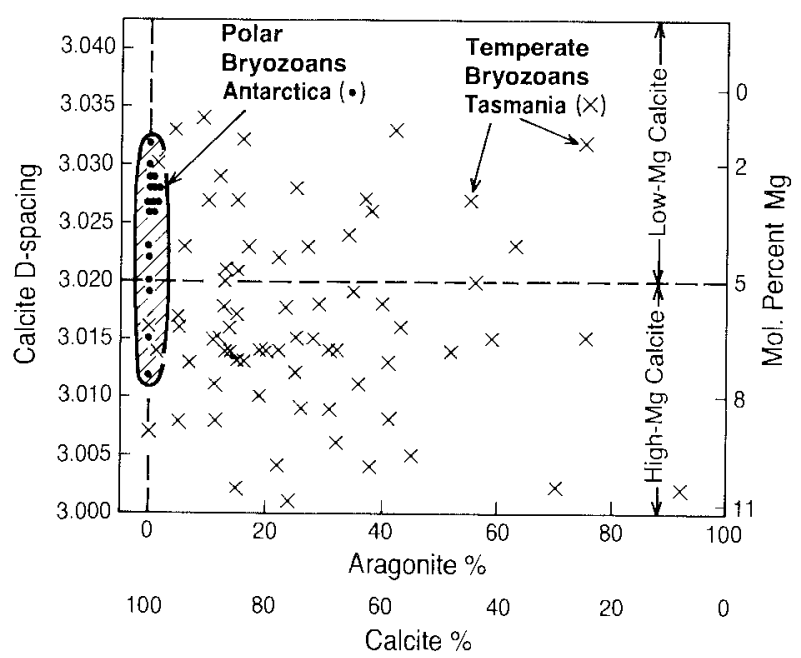

FIG. 2 - Calcite d-spacing versus relative percentages of calcite and aragonite. Note - polar bryozoans from Antarctica are mainly low-Mg calcite with minor high-Mg calcite without aragonite, whereas Tasmanian bryozoans are mainly high-Mg calcite with minor low-Mg calcite and variable amounts of aragonite. Mole \% $\mathrm{MgCO}_{3}$ shown is based on calcite dspacings.

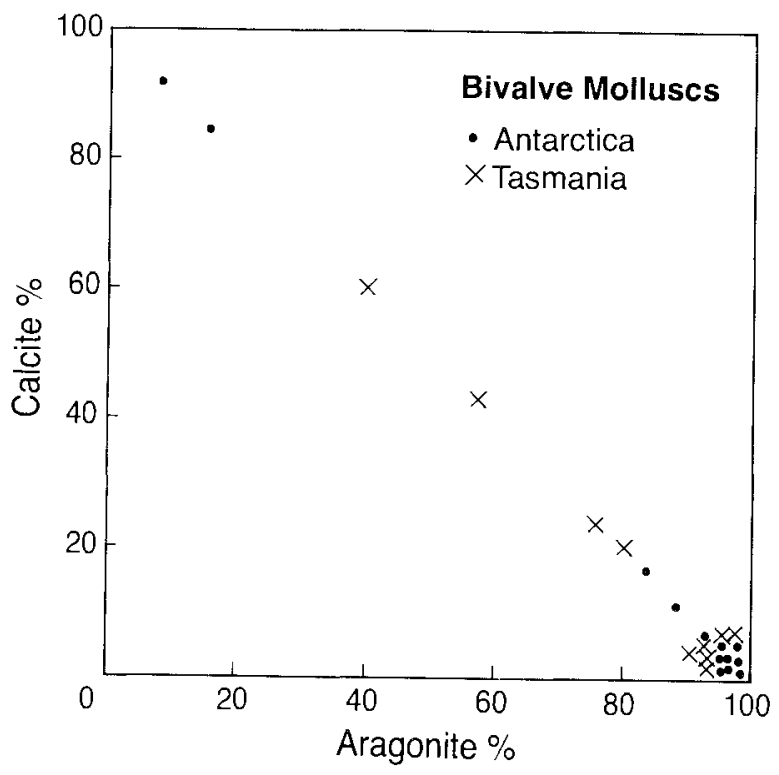

FIG. 3 - Relative percentages of calcite and aragonite in bivalve molluscs from Antarctica and Tasmania. Note-bivalve molluscs from both Antarctica and Tasmania are predominantly aragonite with variable amounts of calcite, which is low-Mg calcite.

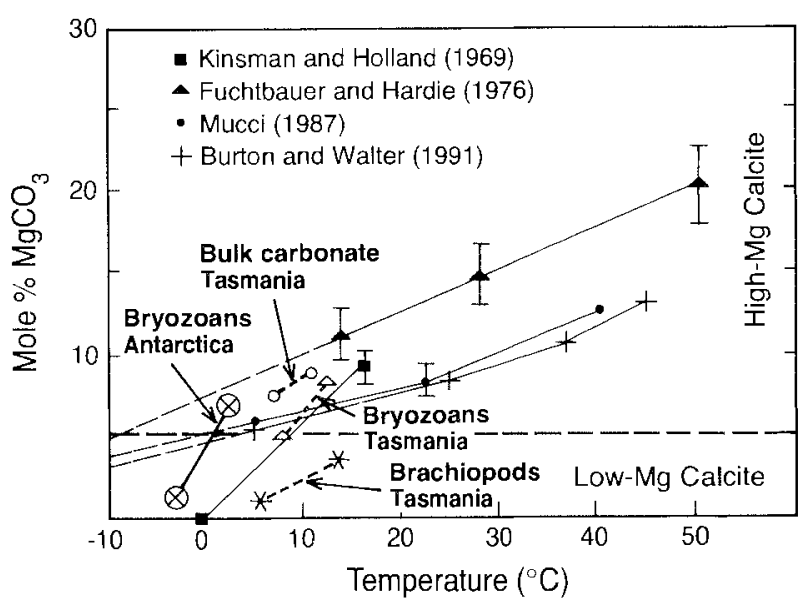

FIG. 4 - Mole \% $\mathrm{MgCO}_{3}$ in calcite and seawater temperatures. Note - mole\% $\mathrm{MgCO}_{3}$ in calcite decreases with decreasing seawater temperatures both in experimental studies on abiotic calcite (Kinsman of Holland 1969, Fuchtbauer of Hardie 1976, Mucci 1987, Burton \& Walter 1991) and in bryozoans from Antarctica and Tasmania.

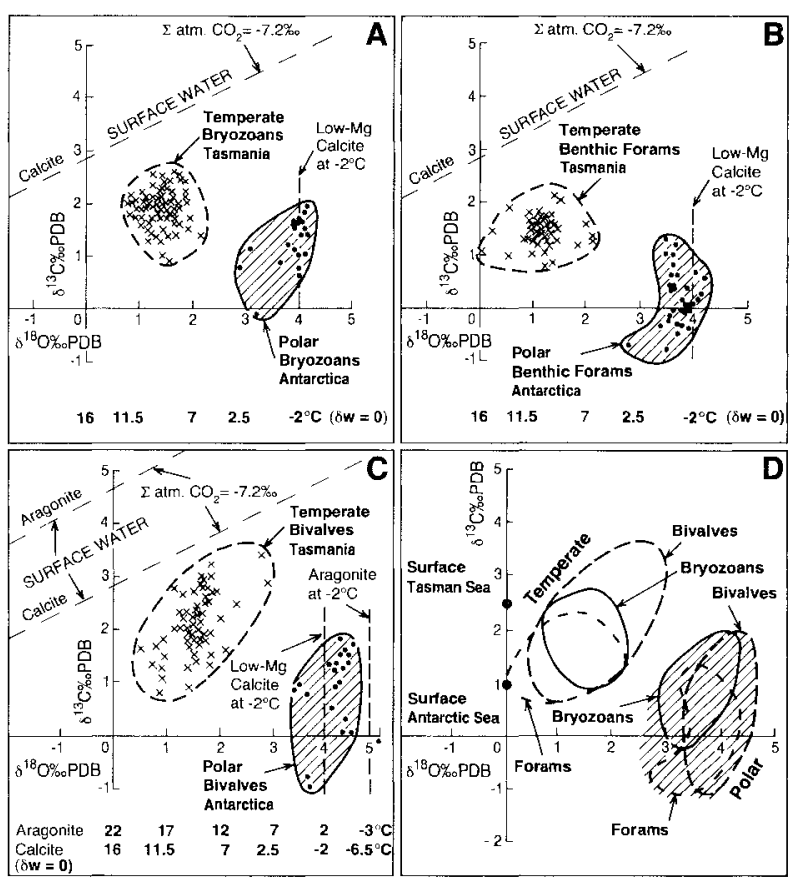

FIG. $5-\delta^{18} O$ and $\delta^{13} C$ fields of bryozoa (A), benthic foraminifera $(B)$, bivalve molluscs $(C)$, and composite fields of skeletons (D) from Tasmania and Antarctica. Surface equilibrium calcite and aragonite lines (Rao 1993) and seawater temperatures obtained from $\delta^{18} O$ values of calcite and aragonite and $\delta^{13} \mathrm{C}$ in atmosphere. $\delta^{13} \mathrm{C}$ values in surface seawater off Tasmania (2.5\%o) and Antarctica (1\%o) vary (Kroopnick et al. 1977, Kroopnick 1985). Note - the isotope fields of polar skeletons are clearly separated from temperate ones, due to differences in seawater temperatures, $\delta^{13} \mathrm{C}$ in seawater and the circulation of seawater masses. See text for details. 
TABLE 1

$\delta^{18} \mathrm{O}$ and $\delta^{13} \mathrm{C}$ values* of bivalves, bryozoans and foraminifera from Prydz Bay, Antarctica and $\delta^{18} \mathrm{O}$ and $\delta^{13} \mathrm{C}$ values of bivalves from eastern Tasmania

\begin{tabular}{|c|c|c|c|c|c|c|c|c|c|c|c|c|}
\hline \multirow[b]{3}{*}{ Sample No } & \multirow[b]{3}{*}{ Depth, m } & \multicolumn{11}{|c|}{ Antarctica } \\
\hline & & \multicolumn{2}{|c|}{ Bivalves } & \multicolumn{2}{|c|}{ Bryozoans } & \multicolumn{2}{|c|}{ Foraminifera } & \multicolumn{3}{|c|}{ Bryozoans } & \multicolumn{2}{|c|}{ Bivalves } \\
\hline & & $\partial^{13} \mathrm{C}$ & $\partial^{18} \mathrm{O}$ & $\partial^{13} \mathrm{C}$ & $\partial^{18} \mathrm{O}$ & $\partial^{13} \mathrm{C}$ & $\partial^{18} \mathrm{O}$ & $\begin{array}{c}\text { Calcite } \\
\text { d-Spacing }\end{array}$ & $\begin{array}{c}\text { Calcite } \\
\%\end{array}$ & $\begin{array}{c}\text { Aragonite } \\
\%\end{array}$ & $\begin{array}{c}\text { Calcite } \\
\%\end{array}$ & $\begin{array}{c}\text { Aragonite } \\
\%\end{array}$ \\
\hline 93009 & Grab 98 & & & & & 0.303 & 3.897 & & & & & \\
\hline $93031 \mathrm{C}$ & Grab 101 & & & & & 0.142 & 3.933 & & & & & \\
\hline 93035 & Grab 88 & & & & & 0.133 & 4.122 & & & & & \\
\hline $93036 \mathrm{~A}$ & Grab 69 & & & -0.152 & 3.202 & 0.236 & 4.132 & 3.019 & 100 & 0 & & \\
\hline 93037 & Grab 95 & & & & & -0.082 & 3.958 & & & & & \\
\hline $93038 \mathrm{C}$ & Grab 110 & 0.764 & 3.67 & 1.135 & 3.036 & -0.336 & 3.865 & 3.012 & 100 & 0 & 90 & 10 \\
\hline 93040 & Grab 85 & 0.841 & 3.407 & 0.757 & 2.89 & 0.028 & 3.945 & 3.015 & 100 & 0 & 84 & 16 \\
\hline 93058 & Grab 38 & 0.936 & 3.502 & & & -0.273 & 3.72 & & & & & \\
\hline 93099 & Grab 26 & & & & & -0.169 & 3.56 & & & & & \\
\hline 93102 & Grab 21 & -0.8 & 3.75 & & & & & & & & & \\
\hline 93103 & Grab 21 & & & & & -0.715 & 2.858 & & & & & \\
\hline 93104 & Grab 33 & 0.307 & 4.361 & & & 0.338 & 3.965 & & & & 7 & 93 \\
\hline 93108 & Grab 30 & & & & & 1.304 & 3.529 & & & & & \\
\hline 93132 & Grab 76 & & & & & -0.693 & 3.34 & & & & & \\
\hline JMW3 & Grab 5 & 0.909 & 4.179 & & & 0.67 & 4.022 & & & & & \\
\hline JMW6 & Grab 5 & 0.974 & 4.264 & & & -0.03 & 3.991 & & & & 16 & 84 \\
\hline Bivalve 1 & Grab 0 & 1.528 & 4.227 & & & & & & & & 0 & 100 \\
\hline Bivalve 2 & Grab 0 & 1.255 & 4.303 & & & & & & & & 0 & 100 \\
\hline Bivalve 3 & Grab 0 & 1.659 & 4.268 & & & & & & & & & \\
\hline Bivalve 4 & Grab 0 & 1.802 & 4.222 & & & & & & & & 0 & 100 \\
\hline Bivalve 5 & Grab $\quad 0$ & 1.29 & 4.176 & & & & & & & & 0 & 100 \\
\hline Bivalve 6 & Grab 0 & 1.319 & 4.092 & & & & & & & & 0 & 100 \\
\hline Bivalve Lat 1 & Grab 0 & 1.349 & 4.398 & & & & & & & & & \\
\hline Bivalye Lat 2 & Grab 0 & 1.719 & 4.452 & & & & & & & & & \\
\hline Bivalve Lat 3 & Grab 0 & 1.351 & 4.193 & & & & & & & & & \\
\hline Bivalye Lat 4 & Grab $\quad 0$ & 1.497 & 4.409 & & & & & & & & & \\
\hline Gco3-12.5cm & Core 134 & & & 1.216 & 3.793 & 1.072 & 3.462 & & & & & \\
\hline $\mathrm{Gco} 3-15 \mathrm{~cm}$ & Core 134 & 0.576 & 4.065 & 1.934 & 4.166 & 1.183 & 3.682 & & & & & \\
\hline $\mathrm{G} \operatorname{co} 3-17.5 \mathrm{~cm}$ & Core 134 & & & 1.686 & 4.073 & 1.038 & 3.676 & 3.028 & 100 & 0 & & \\
\hline$G \operatorname{co} 3-20 \mathrm{~cm}$ & Core 134 & -1.07 & 3.744 & 1.676 & 4.055 & 0.353 & 3.644 & 3.032 & 100 & 0 & & \\
\hline$G \operatorname{co} 3-22.5 \mathrm{~cm}$ & Core 134 & & & 1.826 & 4.17 & 0.559 & 3.613 & & & & & \\
\hline Gco3-25cm & Core 134 & & & 1.646 & 3.914 & -0.795 & 3.572 & & & & & \\
\hline$G \operatorname{co} 3-27.5 \mathrm{~cm}$ & Core 134 & & & 1.584 & 4.048 & 0.366 & 3.562 & 3.029 & 100 & 0 & & \\
\hline $\mathrm{Gco} 3-30 \mathrm{~cm}$ & Core 134 & & & 1.665 & 3.904 & 0.82 & 3.614 & 3.03 & 100 & 0 & & \\
\hline$G \operatorname{co} 3-32.5 \mathrm{~cm}$ & Core 134 & -0.07 & 5.011 & 1.155 & 3.902 & 0.604 & 3.717 & 3.03 & 100 & 0 & & \\
\hline Gco3-35cm & Core 134 & & & 1.264 & 4.105 & 0.393 & 3.636 & 3.026 & 100 & 0 & & \\
\hline Gco $3-37.5 \mathrm{~cm}$ & Core 134 & 0.038 & 4.432 & 1.536 & 4.107 & 0.435 & 3.651 & 3.023 & 100 & 0 & & \\
\hline $\mathrm{Gco} 3-40 \mathrm{~cm}$ & Core 134 & & & 0.623 & 4.033 & -0.039 & 3.696 & 3.029 & 100 & 0 & & \\
\hline $\mathrm{G} \cos 3-42.5 \mathrm{~cm}$ & Core 134 & & & 1.382 & 4.129 & -0.033 & 3.846 & 3.029 & 100 & 0 & & \\
\hline $\mathrm{Gco} 3-45 \mathrm{~cm}$ & Core 134 & & & 0.774 & 4.085 & 0.087 & 3.959 & 3.026 & 100 & 0 & & \\
\hline $\mathrm{Gco} 3-47.5 \mathrm{~cm}$ & Core 134 & & & 1.082 & 4.11 & 0.122 & 3.799 & 3.027 & 100 & 0 & & \\
\hline $\mathrm{G} \operatorname{co} 3-50 \mathrm{~cm}$ & Core 134 & & & 1.025 & 4.075 & 0.07 & 3.777 & 3.02 & 100 & 0 & & \\
\hline Gco $3-52.5 \mathrm{~cm}$ & Core 134 & & & 0.863 & 3.657 & 0.548 & 4.198 & 3.022 & 100 & 0 & & \\
\hline $\mathrm{Gco} 3-55 \mathrm{~cm}$ & Core 134 & 0.052 & 4.318 & 1.401 & 4.089 & -0.514 & 3.731 & 3.027 & 100 & 0 & & \\
\hline $\mathrm{Gco} 3-57.5 \mathrm{~cm}$ & Core 134 & & & 1.567 & 3.987 & 0.007 & 3.825 & 3.028 & 100 & 0 & & \\
\hline
\end{tabular}

* X-ray diffraction data pertaining to calcite d-spacing and relative per cent of calcite and aragonite of bryozoans and bivalves from Prydz Bay, Antarctica, and bivalves from eastern Tasmania.

to variable rates of skeletal precipitation. Equilibrium $\delta^{18} \mathrm{O}$ values occur at slow rates of skeletal precipitation, and disequilibrium $\delta^{18} \mathrm{O}$ values at faster rates (McConnaughey 1989, Rao 1994). Since $\delta^{18} \mathrm{O}$ values of most Antarctic bryozoans are in equilibrium with seawater temperatures of around $-2^{\circ} \mathrm{C}$, and $\delta^{18} \mathrm{O}$ values of most Antarctic benthic foraminifera and bivalve molluscs are in slight disequilibrium with an average temperature of $-2^{\circ} \mathrm{C}$, it appears that Antarctic bryozoan skeletons formed at a slow rate. In contrast, $\delta^{18} \mathrm{O}$ values of benthic foraminifera and bivalve mollucs suggests that they formed at a faster rate than bryozoans. In Tasmania, temperate benthic foraminifera $\delta^{18} \mathrm{O}$ values are lower than those of bryozoans in the same samples, due to benthic foraminifera forming at a faster rate than bryozoans (Rao 1994).

Experimental studies indicate abiotic calcite $\delta^{13} \mathrm{C}$ values are inversely related to the rate of calcite formation (Turner 1982). The $\delta^{13} \mathrm{C}$ values of Antarctic bryozoans are higher than those of benthic foraminifera and bivalve molluscs (fig. 8), due to the slower rate of bryozoan skeletal precipitation than of benthic foraminifera and bivalve molluscs. Since the percentile distribution curves of $\delta^{13} \mathrm{C}$ of benthic 
Table 1 cont.

\begin{tabular}{|c|c|c|c|c|c|}
\hline \multirow[b]{3}{*}{ Samples } & \multirow[b]{3}{*}{ Depth, m } & \multicolumn{4}{|c|}{ Tasmania } \\
\hline & & \multicolumn{4}{|c|}{ Bivalves } \\
\hline & & $\partial^{13} \mathrm{C}$ & $\partial^{18} \mathrm{O}$ & $\begin{array}{c}\text { Calcite } \\
\%\end{array}$ & $\begin{array}{c}\text { Aragonite } \\
\% \\
\end{array}$ \\
\hline 2000 & 106 & 2.315 & 1.655 & & \\
\hline 2001 & 184 & 2.887 & 1.66 & & \\
\hline 2003 & 45 & 1.236 & 1.429 & & \\
\hline 2004 & 42 & 0.817 & 0.796 & & \\
\hline 2006 & 18 & 1.05 & 0.8 & 0 & 100 \\
\hline 2007 & 24 & 1.361 & 0.729 & 0 & 100 \\
\hline 2010 & 16 & 1.613 & 2.123 & & \\
\hline 2011 & 14 & 1.482 & 0.973 & & \\
\hline 2013 & 88 & 2.325 & 1.565 & & \\
\hline 2014 & 70 & 1.8 & 1.475 & & \\
\hline 2015 & 28 & 2.747 & 1.149 & & \\
\hline 2016 & 64 & 2.684 & 1.295 & & \\
\hline 2017 & 205 & 2.863 & 2.284 & & \\
\hline 2018 & 104 & 2.103 & 1.616 & & \\
\hline 2020 & 100 & 2.436 & 1.716 & & \\
\hline 2021 & 73 & 2.417 & 1.522 & 43 & 57 \\
\hline 2024 & 53 & 1.423 & 1.548 & & \\
\hline 2025 & 33 & 2.376 & 1.625 & 0 & 100 \\
\hline 2026 & 60 & 1.514 & 1.506 & 0 & 100 \\
\hline 2027 & 84 & 2.797 & 1.751 & 24 & 76 \\
\hline 2028 & 128 & 3.008 & 1.603 & & \\
\hline 2033 & 31 & 2.297 & 1.377 & 0 & 100 \\
\hline 2034 & 71 & 1.723 & 1.396 & 19 & 81 \\
\hline 2043 & 60 & 2.184 & 1.297 & & \\
\hline 2044 & 60 & 2.099 & 1.168 & & \\
\hline 2047 & 33 & 1.277 & 1.821 & & \\
\hline 2049 & 62 & 2.097 & 1.379 & & \\
\hline 2050 & 82 & 1.858 & 1.605 & & \\
\hline 2051 & 399 & 2.497 & 2.308 & & \\
\hline 2052 & 113 & 3.244 & 1.809 & 60 & 40 \\
\hline 2054 & 161 & 3.415 & 2.771 & & \\
\hline 2055 & 62 & 2.2 & 1.994 & & \\
\hline 2056 & 121 & 2.622 & 1.744 & & \\
\hline 2057 & 146 & 2.713 & 1.824 & & \\
\hline 2059 & 175 & 2.575 & 1.736 & & \\
\hline 2060 & 84 & 1.971 & 1.418 & & \\
\hline 2061 & 128 & 2.168 & 1.574 & & \\
\hline 2062 & 148 & 2.281 & 1.541 & & \\
\hline 2064 & 154 & 2.741 & 1.857 & & \\
\hline 2065 & 95 & 3.021 & 1.811 & & \\
\hline 2066 & 104 & 2.75 & 1.535 & & \\
\hline 2067 & 124 & 2.854 & 1.62 & & \\
\hline 2068 & 168 & 3.574 & 1.932 & & \\
\hline 2076 & 108 & 2.834 & 1.678 & 0 & 100 \\
\hline 2077 & 97 & 2.244 & 1.493 & & \\
\hline
\end{tabular}

foraminifera and bivalve molluscs overlap (fig. 8), both these faunal elements probably formed at almost equal growth rates. In Tasmania, $\delta^{13} \mathrm{C}$ values of temperate benthic foraminifera are lower than those of bryozoans in the same samples, due to benthic foraminifera forming at a faster rate (Rao 1994).

The $\delta^{13} \mathrm{C}$ values in skeletons depend on $\delta^{13} \mathrm{C}$ in seawater, which ranges up to about $2.5 \%$ in shallow seas and to about $\% \%$ in well-mixed deep seawater (Kroopnick et al. 1977 , Kroopnick 1985). The difference in $\delta^{13} \mathrm{C}$ values in polar Antarctic skeletons and temperate Tasmanian skeletons (fig. 5D) is due to lower $\delta^{13} \mathrm{C}$ values in polar Antarctic surface seawater $(1 \%)$ than in cool temperate

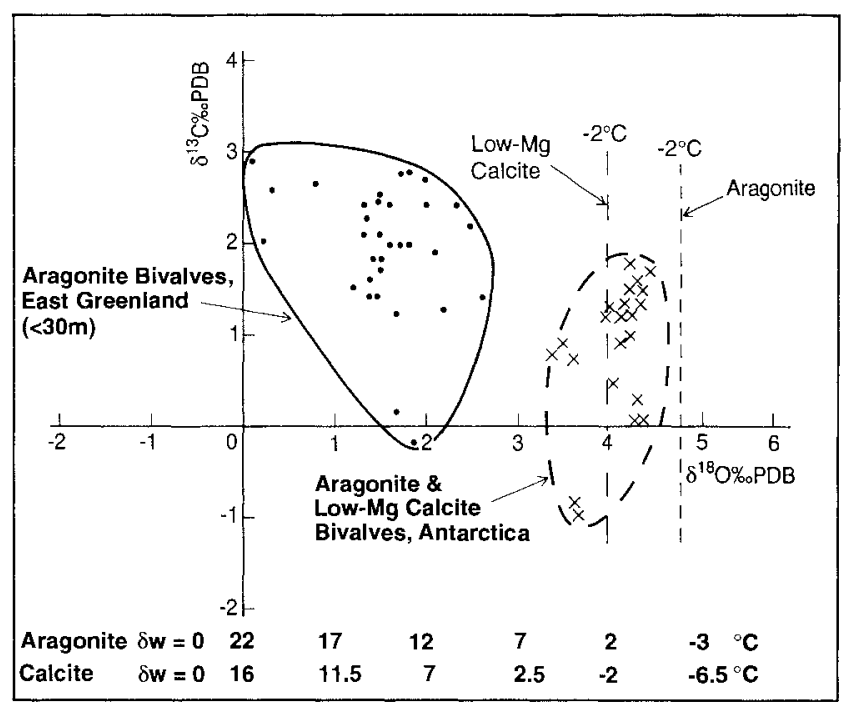

FIG. 6 - Comparison of $\delta^{18} \mathrm{O}$ and $\delta^{13} \mathrm{C}$ values of bivalves from Antarctic and Greenland waters (Israelson et al. 1994). Note - though seawater temperatures in both regions are cold (around $1^{\circ}$ to $-1.5^{\circ} \mathrm{C}$ off Greenland and $-1.8^{\circ} \mathrm{C}$ off Antarctica), the temperatures determined from $\delta^{18} O$ values of bivalves are warmer than those measured, due to meltwater effect during the growth of bivalves. See text for details.

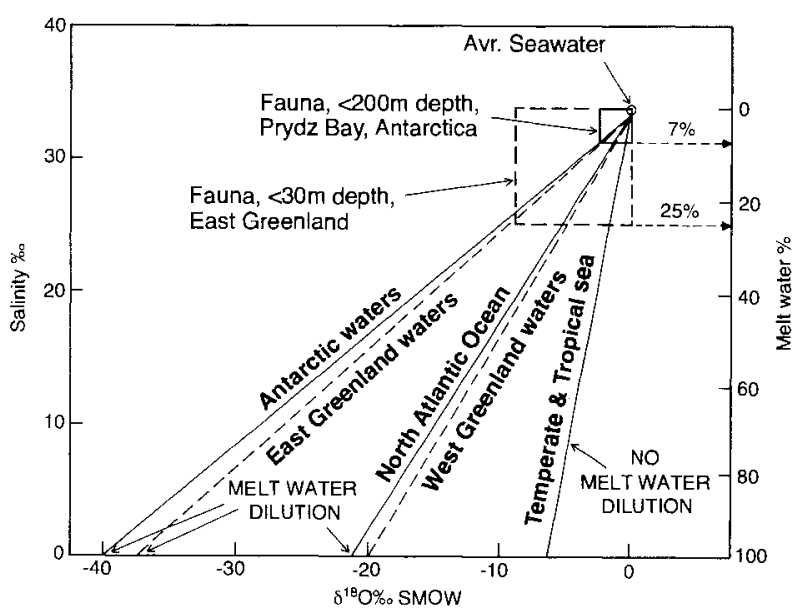

FIG. 7 - Salinity versus ${ }^{18} \mathrm{O}$ composition of seawater with meltwater dilution around Antarctica, off Greenland and in the North Atlantic Ocean, and in temperate to tropical seas with no meltwater dilution. See text for details.

Tasmanian surface seawater (2.5\% ; Kroopnick et al. 1977). The $\delta^{13} \mathrm{C}$ values in tropical surface seawater are around $2 \%$ and change laterally, depending on depositional environments, to lower values by as much as $4 \%$, due to evaporation, freshwater discharge and $\mathrm{CaCO}_{3}$ withdrawal (Patterson \& Walter 1994). In non-tropical shallow seas, evaporation of seawater is too low to cause significant shifts in $\delta^{13} \mathrm{C}$ values. Freshwater input from rivers is minimal in the Tasman Sea (e.g. Rao \& Huston 1995). Only small amounts of meltwater are added to the Antarctic waters, because Antarctica is the driest continent and the atmospheric temperatures are not warm enough to melt ice appreciably. As for $\delta^{18} \mathrm{O}, \delta^{13} \mathrm{C}$ values of these marine 


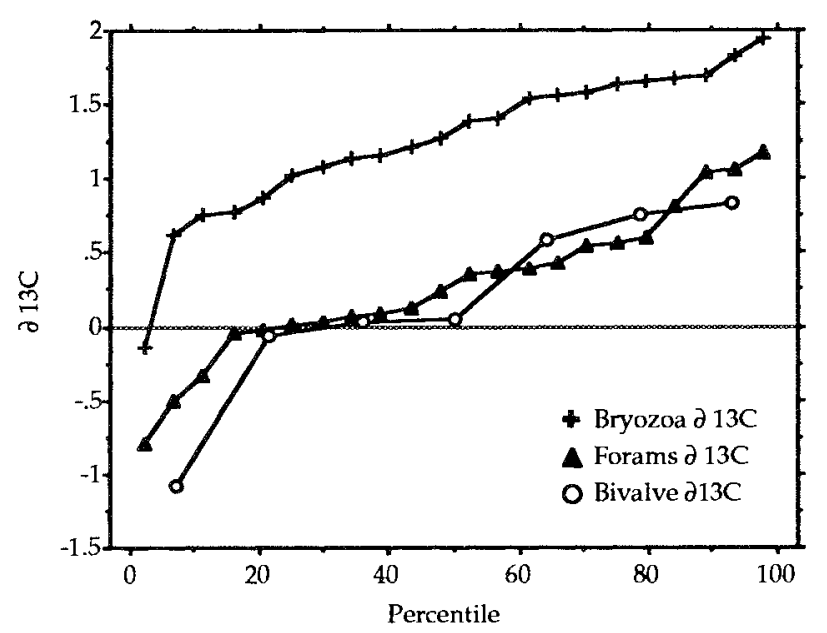

FIG. 8-Percentile distribution of $\delta^{13} \mathrm{C}$ values in bryozoans, benthic foraminifera and bivalve molluscs from samples that contain all these three skeletons. Note - the $\delta^{13} \mathrm{C}$ distribution curve of bryozoans is above those of benthic foraminifera and bivalve molluscs, due to higher $\delta^{13} C$ values in bryozoans than in other skeletons.

waters are not significantly affected by freshwater input. The rate of $\mathrm{CaCO}_{3}$ production in non-tropical seas is lower than in tropical seas (Rao 1994) and, thus, the withdrawal of $\delta^{13} \mathrm{C}$ from non-tropical seas is too low to significantly decrease $\delta^{13} \mathrm{C}$ values in those seas. Kinctic effects are minimal in non-tropical skeletons (Rao 1993), so the variation in $\delta^{13} \mathrm{C}$ values in skeletons is due to mixing of seawater masses. Lower $\delta^{13} \mathrm{C}$ values in some Antarctic skeletons compared with Tasmanian ones, therefore, are due to strong mixing of seawater and oxidation of organic matter. In Prydz Bay, physical oceanographic evidence indicates the operation of a large cyclonic effect (Smith et al. 1984), and this affects the distribution of fauna and sediment types (Franklin 1993). Carbonates around Antarctica are observed to be preserved in areas of strong upwelling (Domack 1988, Taviani et al. 1993). Off Tasmania, $\delta^{18} \mathrm{O}$ and $\delta^{13} \mathrm{C}$ values of skeletons indicate mixing of shelf waters with warm, Coral Sea water in summer, with cold subantarctic water in winter, and with upwelled cold, deep water all year round (Rao \& Huston 1995).

\section{GEOLOGIC IMPLICATIONS}

A significant problem in sedimentary geology is the recognition of ancient non-tropical carbonates. Modern temperate and polar shelf carbonates extend over large areas (e.g. Domack 1988, Nelson 1988), yet anomalously few ancient polar carbonates have been recognised (Rao 1981, Rao \& Green 1982). Modern temperate and polar carbonates are mainly biogenic. Bryozoa, foraminifera and mollusca are the major fauna in non-tropical carbonates (e.g. Nelson 1988). Importantly, many ancient limestones contain abundant bryozoans, foraminifera and molluscs (Wilson 1975). Carbonate mineralogy and elemental and isotopic composition of ancient carbonates suggest extensive nontropical carbonates worldwide (e.g. Rao \& Jayawardane 1994). Since bryozoa skeletal mineralogy is dependent on seawater temperature in modern temperate Tasmanian and polar Antarctic shelves, the original skeletal calcitic mineralogy is important in the recognition of ancient nontropical carbonates and terrigenous clastic sediments that contain skeletons. Heavy $\delta^{18} \mathrm{O}$ values indicate non-tropical or hypersaline environments (Taviani 1991). $\delta^{18} \mathrm{O}$ values of bryozoa, benthic foraminifera and mollusca in non-tropical shallow seas, unaffected by meltwater dilution, give nearequilibrium seawater temperatures (Rao 1994); thus, these skeletal values can be used in the determination of palaeotemperatures (Taviani \& Aharon 1989). Bryozoan $\delta^{18} \mathrm{O}$ values are excellent palaeoclimatic indicators (Rao 1993, Bone \& James 1995) because their skeletons form at a slower rate than benthic foraminifera and bivalve molluses. The differences in $\delta^{18} \mathrm{O}$ and $\delta^{13} \mathrm{C}$ between bryozoans, benthic foraminifera and bivalve mollusca are due to variable growth rates, which determine the relative frequency abundances of skeletons in modern environments (Rao 1994). Similar relationships can occur in the geologic record. In contrast to tropical shallow seas, evaporation rates, freshwater discharge and $\mathrm{CaCO}_{3}$ rate of formation are low in temperate and polar shallow seas with minor meltwater dilution. Thus non-tropical skeletal $\delta^{13} \mathrm{C}$ values are due to mixing of seawater masses, oxidation of organic matter and cooler temperatures. Last Glacial carbonates formed around Antarctica have similar $\delta^{18} \mathrm{O}$ and $\delta^{13} \mathrm{C}$ values to modern Antarctic skeletons, because the Pleistocene glacial bank carbonates $(>200 \mathrm{~m}$ ) have not been affected by meltwater dilution (Taviani et al. 1993). In regions of strong meltwater dilution, both $\delta^{18} \mathrm{O}$ and $\delta^{13} \mathrm{C}$ values of skeletons will appreciably decrease from original marine values, as in the modern sea off Greenland (Israelson et al. 1994), the Canadian Arctic (Hillaire-Marcel 1981) and the polar Permian sea of Tasmania (Rao \& Green 1982).

\section{ACKNOWLEDGEMENTS}

This project is funded by the Australian Antarctic Science Advisory Committee. We thank the Antarctic CRC and AGSO for providing samples, Mike Power and Christine Cook for isotope analysis, Debbie Harding for drafting illustrations and Mohammad Adabi, Peter Harris and Andrew McMinn for reading earlier versions of the manuscript. We also thank $M$. Taviani and an anonymous reviewer for valuable comments.

\section{REFERENCES}

Anderson, J.B., Reid, D.E. \& Taviani, M., 1992: Compositional and geochemical characteristics of Recent biogenic carbonates from the Ross Sea (Antarctica). Mem. Soc. Geol. Italy 46: 561-562.

Barrerra, E., Tevesz, M.J.S., Carter, J.G. \& McCall, P.L., 1994: Oxygen and carbon isotopic composition of shell microstructure of the bivalve Laternula elliptica from Antarctica. Palaios 9: 275-287.

BONE, Y. \& JAMES, N.P., 1995: Cool-water bryozoa and stable isotopes. COOL AND COLD-WATER CARBONATE CONFERENCE ABSTRACTS, VICTORIA, AUSTRALIA. Geological Society of Australia Specialist Group in Sedimentology: 9-10.

BURTON, E.A. \& WALTER, L.K., 1991: The effects of $\mathrm{pCO}_{2}$ and temperature on magnesium incorporation in calcite in 
seawater and $\mathrm{MgCl}_{2}-\mathrm{CaCl}_{2}$ solutions. Geochim. Cosmochim. Acta 55: 777-785.

DOMaCK, E.W., 1988: Biogenic facies in the Antarctic glacimarine environment: Basis for a polar glacimarine summary. Palaeogeogr. Palaeoclimatol. Palaeoecol. 63: 357-372.

FRANKLIN, D.C., 1993: Recent diatom and foraminiferal assemblages in surficial sediments of Prydz Bay, Antarctica. ANARE Res. Notes 90:27 pp.

Friedman, I. \& O'NeIL, J.R., 1977: Compilation of stable isotope fractionation factors of geochemical interest. In Fleischer, M. (Ed.): DATA OF GEOCHEMISTRY. 6th edn. US Geol. Surv. Prof. Pap. 440-KK: 1-12

Fuchtbauer, H. \& Hardie, L.A., 1976: Experimentally determined homogeneous distriburion co-efficients for precipitated magnesian calcites. ABSTRACTS ANNUAL PROGRAM MEETING GEOLOGICAL SOCIETY OF AMERICA: 877.

Grossman, E.L. \& KU, T.L., 1986: Oxygen and carbon isotope fractionation in biogenic aragonite: Temperature effects. Chem. Geol. 59: 59-74.

Harris, P.T, O’Brien, P.E., Sedwick, P. \& Truswell, E.M., 1996: Late Quaternary History of sedimentation on the MacRobertson Shelf, East Antarctica: problems with ${ }^{14} \mathrm{C}$ daring of marine sediment cores. Pap. Proc. R. Soc. Tasm. $130(2): 00-00$

Hillatre-Marcel, C., 1981: Palco-oceanographic isotopique des mers post-glaciares du Quebec. Paleogeogr. Paleoclimatol. Paleoecol. 35: 63-119.

Kinsman, D.J.J. \& Holland, H.D., 1969: The co-precipitation of cations with $\mathrm{CaCO}_{3}-\mathrm{IV}$. The co-precipitation of $\mathrm{S}_{r}^{+2}$ with aragonite between $16^{\circ}$ and $96^{\circ} \mathrm{C}$. Geochim. Cosmochim. Acta 33: 1-17.

KroOpNICK, P.M., 1985: The distribution of ${ }^{13} \mathrm{C}$ of $\mathrm{CO}_{2}$ in the world oceans. Deep Sea Res, 32: 57-84.

Kroopnick, P.M., Margolis, S.V. \& Wong, C.S., 1977: 13C variations in marine carbonate sediments as indicators of the $\mathrm{CO}_{2}$ balance between the atmosphere and the oceans. In Anderson, N.R. \& Malahoff, A.(Eds): THE FATE OF FOSSIL FUEL $\mathrm{CO}_{2}$ IN THE OCEANS. Plenum Press, New York, NY: 305-321.

Israelson, C., Buchardt, B., Funder, S. \& Hubberten, H.W., 1994: Oxygen and carbon isotope composition of Quaternary bivalve shells as a water mass indicator: Last interglacial and Holocenc, East Greenland. Paleogeogr. Paleoclimatol. Paleoecol. 111: 119-134.

MCCOnnaughey, $\mathrm{T}, 1989{ }^{13} \mathrm{C}$ and ${ }^{18} \mathrm{O}$ isotopic disequilibrium in biological carbonates. I. Patterns. Geochim. Cosmochim. Acta 53: 151-162.

Morse, J.W. \& MACKENZIE, F.T., 1990: GEOCHEMISTRY OF SEDIMENTARY CARBONATES. Elsevier, Amsterdam: $707 \mathrm{pp}$.

Muccl, A., 1987: Influence of temperature on the composition of magnesian calcite overgrowths precipitated from seawater. Geochem. Cosmochim. Acta 5: 1977-1984.

NeLson, C.S., 1988: An introductory perspective on non-tropical shelf carbonates. Sediment. Geol. 60: 3-12.
Patterson, W.P. \& Walter, L.M., 1994: Depletion of ${ }^{13} \mathrm{C}$ in seawater $\Sigma \mathrm{CO}_{2}$ in modern carbonate platforms: Significance for the carbon isotopic record of carbonates. Geology 22: 885-888.

RAO, C.P., 1981: Criteria for recognition of cold-water carbonate sedimentation: Berriedale Limestone (Lower Permian), Tasmania, Australia. J. Sediment. Petrol. 53: 117-129.

Rao, C.P., 1993: Carbonate minerals, oxygen and carbon isotopes in modern temperate bryozoa, eastern Tasmania, Australia. Sediment. Geol. 88: 123-135.

RAO, C.P., 1994: Implications of isotopic fractionation and temperature on rate of formation of temperate shelf carbonates, eastern Tasmania, Australia. Carbonates Evaporites 9: 33-41.

RAO, C.P. \& GREEN, D., 1982: Oxygen and carbon isotopes of Early Permian cold-water carbonates of Tasmania, Australia. J. Sediment. Petrol. 52: 1111-1125.

RAO, C.P. \& Huston, D., 1995: Temperate shelf carbonates reflect mixing of distinct water masses, eastern Tasmania, Australia. Carbonates Evaporites 1: 105-113.

RAO, C.P. \& JaYAWARDANE, M.P.J., 1994: Major minerals, elemental and isotopic composition in modern temperate shelf carbonates, eastern Tasmania, Australia: Implications for the occurrence of extensive ancient non-tropical carbonates: Paleogeogr. Paleoclimatol. Paleoecol. 107: 4963.

Smith, N.R., Dong, Z., Kerry, K.R. \& WRight, S., 1984: Water masses and circulation in the region of Prydz Bay, Antarctica. Deep Sea Res. 31: 1121-1147.

Stuiver, M., Denton, G.H., Hughes, T.J. \& Fastook, J.L., 1981: History of marine ice sheet in West Antarctica during last glaciation: a working hypothesis. In Denton, G.H. \& Hughes, T.J. (Eds): THE LAST GREAT ICE SHEETS. Wiley Interscience, New York: 319-436.

TAVIANI, M., 1991: Stable isotope composition of Recent Antarctic biogenic carbonates and its bearing to the problem of ancient cold water limestones. 6TH INTERNATIONAL SYMPOSIUM, ANTARCTIC EARTH SCIENCES TOKYO, ABSTRACTS. National Institute of Polar Rescarch: 577.

Taviani, M. \& Aharon, 1989: An assessment of stable isotope composition of calcareous modern benthic fauna from the Ross Sea (Antarctica). Antarct. J. US 24: 131-132.

TaViani, M., Reid, D.E. \& ANderson, J.B., 1993: Skeletal and isotopic composition and paleoclimatic significance of Late Pleistocene carbonates, Ross Sea, Antarctica. J. Sediment. Petrol. 63: 84-90.

Turner, J.V., 1982: Kinetic fractionation of carbon-13 during calcium carbonate precipitation: Geochim.Cosmochim. Acta 46: 1183-1191.

WILSON, J.L., 1975: CARBONATE FACIES IN GEOLOGIC TIME. Springer-Verlag, New York: 471 pp.

(accepted 13 August 1996) 